\title{
Investigation of Texturization for Monocrystalline Silicon Solar Cells with $\mathrm{K}_{3} \mathrm{PO}_{4} / \mathrm{K}_{2} \mathrm{HPO}_{4}$ Solutions
}

\author{
Qian-Run Zhao \\ School of physics and electronic information \\ technology, Yunnan normal university \\ Kunming, Yunnan, China \\ zqrfyq2007@163.com
}

Jun-Qi Tang

School of physics and electronic information technology, Yunnan normal university

Kunming, Yunnan, China

240977838@qq.com

\author{
Ning Zhang \\ School of physics and electronic information \\ technology, Yunnan normal university \\ Kunming, Yunnan, China \\ miccozn@163.com \\ Shi-Qing Man* \\ School of physics and electronic information \\ technology, Yunnan normal university \\ Kunming, Yunnan, China \\ tsqman@jnu.edu.cn
}

\begin{abstract}
The texturization of monocrystalline silicon wafers using a mixture of potassium phosphate tribasic $\left(\mathrm{K}_{3} \mathrm{PO}_{4}\right)$ and potassium phosphate dibasic $\left(\mathrm{K}_{2} \mathrm{HPO}_{4}\right)$ solutions has been investigated. A series of comparative experiments were made to indicate the dependence of hemispherical surface reflectance on the solution temperature, the etching time, and the concentration of $\mathrm{K}_{3} \mathrm{PO}_{4}$ and $\mathrm{K}_{2} \mathrm{HPO}_{4}$. The hemispherical surface reflectance and the surface morphology were measured with a UVVisible Spectrophotometer and a scanning electronic microscope (SEM), respectively. A wafer with uniform pyramid structures and an average weighted reflectance of $11.27 \%$ was obtained after texturing with the mixed solution of $15 \mathrm{wt} \%$ potassium phosphate tribasic $\left(\mathrm{K}_{3} \mathrm{PO}_{4}\right)$ and $1 \mathrm{wt} \%$ potassium phosphate dibasic $\left(\mathrm{K}_{2} \mathrm{HPO}_{4}\right)$ at $85^{\circ} \mathrm{C}$ for $15 \mathrm{~min}$. our results show that the texturing method based on $\mathrm{K}_{3} \mathrm{PO}_{4} / \mathrm{K}_{2} \mathrm{HPO}_{4}$ solutions is cost effective, has low pollution and good reproducibility, This method is promising for a large-scale production of crystalline silicon solar cells.
\end{abstract}

Keywords-Solar cell; Texturing; Monocrystalline silicon; Phosphate; Reflectance

\section{INTRODUCTION}

The texturization of crystalline silicon solar cells has been widely used with the aim of increasing the conversion efficiency. Anisotropic etching of silicon to form random pyramids is an important technology for the fabrication of mono-crystalline solar cells. The most common etchant is the mixture of sodium hydroxide $(\mathrm{NaOH})$ or potassium hydroxide $(\mathrm{KOH})$ with water and isopropyl alcohol (IPA) ${ }^{[1-5]}$. In those etch solutions, IPA can help not only to remove hydrogen bubbles but also to promote the formation of big pyramids. However, IPA easily pollutes the workshop and is expensive too. In typical texturing condition, the IPA concentration is higher than the $\mathrm{NaOH}$ (or $\mathrm{KOH}$ ) concentration. Thus, the cost of IPA is dominant in the overall cost of texturing in the commercial $\mathrm{NaOH} / \mathrm{KOH}$ technique.

As IPA is an expensive chemical product, other solvents are studied to reduce the cost of the process ${ }^{[6-10]}$ Some researchers have reported the texturization with potassium carbonate $\left(\mathrm{K}_{2} \mathrm{CO}_{3}\right)^{[11]}$, sodium carbonate $\left(\mathrm{Na}_{2} \mathrm{CO}_{3}\right)^{[12]}$, Sodium silicate $\left(\mathrm{Na}_{2} \mathrm{SiO}_{3}\right)^{[13]}$ and sodium phosphate $\left(\mathrm{Na}_{3} \mathrm{PO}_{4}\right)^{[14]}$ solutions. These techniques are superior to the conventional method in terms of cost because there is no need of IPA for texturing.

In this paper, texturization of monocrystalline silicon wafers with a mixture of potassium phosphate tribasic $\left(\mathrm{K}_{3} \mathrm{PO}_{4}\right)$ and potassium phosphate dibasic $\left(\mathrm{K}_{2} \mathrm{HPO}_{4}\right)$ solutions was studied. Meanwhile, the changes of reflectance with etching time, the concentration of $\mathrm{K}_{3} \mathrm{PO}_{4}$ and $\mathrm{K}_{2} \mathrm{HPO}_{4}$ and temperature were also investigated.

\section{EXPERIMENTAL METHED}

Monocrystalline silicon wafers of P-type. $<100>$ oriented and size $1.5 \mathrm{~cm} \times 1.5 \mathrm{~cm}$ with resistivity $1-3 \Omega \cdot \mathrm{cm}$ was used as the etching experiments. Samples were cut from the adjacent wafers. Before etching, wafers were cleaned by the following procedure. The first step was to degrease the samples by cleaning the wafers in ethanol during four minutes of ultrasonic cleaning. The second step the native oxide was removed by immersion of the samples into diluted hydrofluoric acid $(4 \mathrm{wt} \%)$, for $30 \mathrm{~s}$. The cleaned wafer were took place in a specially designed of the sealing device inside the alkaline mixed solution. Then these samples were etching in different mass ratios of potassium phosphate tribasic $\left(\mathrm{K}_{3} \mathrm{PO}_{4}\right)$ and potassium phosphate dibasic $\left(\mathrm{K}_{2} \mathrm{HPO}_{4}\right)$. The different reaction times and reaction temperatures could be controlled. After the etching process the samples were washed again into 
absolute ethanol solution and de-ionized water, they were dried oven for tests.

The total hemispherical reflectance was measured by Shimadzu UV-2600 spectrophotometer (Shimadzu Inc, Japan) equipped with an integrating sphere. The surface morphology was studied with Zeiss EVO MA10 (CarlZeiss, Germany) scanning electron microscope (SEM).

\section{RESULTS AND DISCUSSION}

At first, the dependence of the surface reflectance on solution concentration was investigated. Etching was carried out at $85{ }^{\circ} \mathrm{C}$. The reflectance was measured for samples textured using $1 \mathrm{wt} \% \mathrm{~K}_{2} \mathrm{HPO}_{4}$ solution and different $\mathrm{K}_{3} \mathrm{PO}_{4}$ concentrations $(10 \mathrm{wt} \%, 15 \mathrm{wt} \%$, 20wt $\%$ and $25 \mathrm{wt} \%$ ) for $25 \mathrm{~min}$ at $85^{\circ} \mathrm{C}$. The reflectance curves are shown in Fig. 1. The reflectance was found to decrease with increasing $\mathrm{K}_{3} \mathrm{PO}_{4}$ concentration up to $15 \mathrm{wt} \%$. The weighted average reflectance in the range of $400-800 \mathrm{~nm}$ spectrum range is $12.05 \%$. Fig. 2 show SEM micrographs of monocrystalline silicon wafers textured using $1 \mathrm{wt} \%$ $\mathrm{K}_{2} \mathrm{HPO}_{4}$ solution and different $\mathrm{K}_{3} \mathrm{PO}_{4}$ concentrations $(10 w t \%, 15 w t \%, 20 w t \%$ and $25 w t \%)$ for $25 \mathrm{~min}$ at $85^{\circ} \mathrm{C}$. From the Fig. 2, it can be seen that the texture was excellent. All these mean that this kind of etchant can successfully texture monocrystalline silicon for solar cells. When the $\mathrm{K}_{3} \mathrm{PO}_{4}$ concentration was increased to $20 \mathrm{wt} \%$, the pyramidal structure began to collapse.

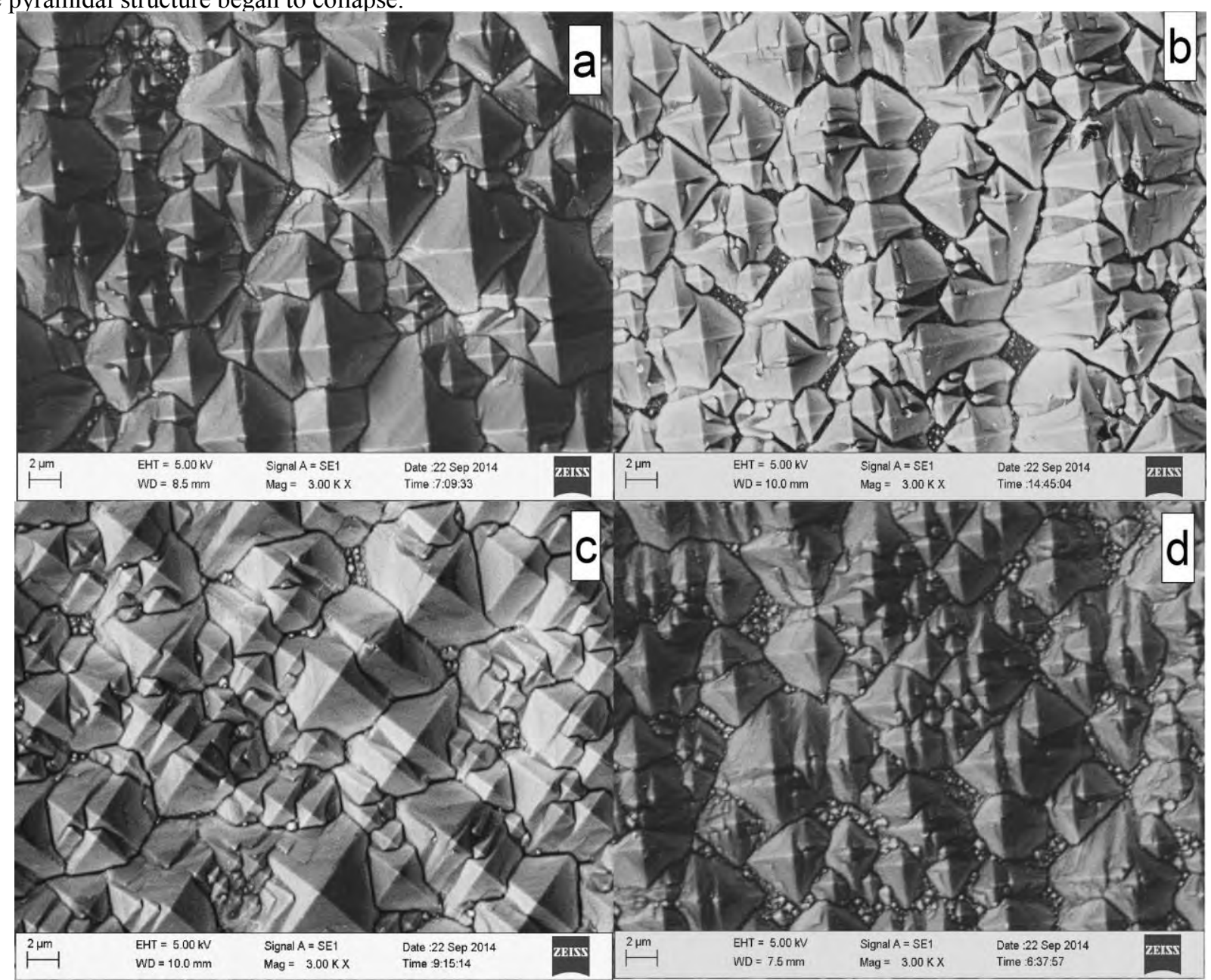

Figure 2. SEM micrographs of monocrystalline silicon wafers textured using $1 \mathrm{wt} \% \mathrm{~K}_{2} \mathrm{HPO}_{4}$ solution and different $\mathrm{K}_{3} \mathrm{PO}_{4}$ concentrations for 25 min at $85^{\circ} \mathrm{C}$ : (a) $10 \mathrm{wt} \%$,(b) $1 \mathrm{wt} \%$,(c) $20 \mathrm{wt} \%$,(d) $25 \mathrm{wt} \%$

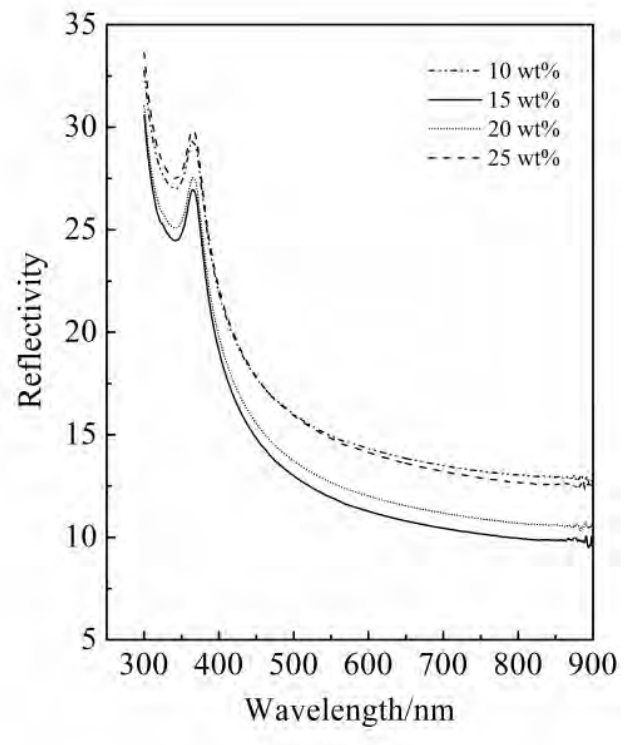

Figure 1. Reflectance curves of monocrystalline silicon wafers textured using $1 \mathrm{wt} \% \mathrm{~K}_{2} \mathrm{HPO}_{4}$ solution and different $\mathrm{K}_{3} \mathrm{PO}_{4}$ concentrations for $25 \mathrm{~min}$ at $85^{\circ} \mathrm{C}$ 
Next, we investigated the dependence of the surface reflectance on etching time. According to previous studies, the concentration of $\mathrm{K}_{2} \mathrm{HPO}_{4}$ and $\mathrm{K}_{3} \mathrm{PO}_{4}$ was fixed at $1 \mathrm{wt} \%$ and $15 \mathrm{wt} \%$, respectively, and the solution temperature fixed at $85^{\circ} \mathrm{C}$. Fig. 3 shows the reflectance curve of the monocrystalline silicon surface textured using $1 \mathrm{wt} \%$ $\mathrm{K}_{2} \mathrm{HPO}_{4}$ solution and $15 \mathrm{wt} \% \mathrm{~K}_{3} \mathrm{PO}_{4}$ at $85^{\circ} \mathrm{C}$ for different reaction time. As shown in Fig. 3, at a fixed etching solution and temperature, the reflectance of the textured surfaces decreases with increasing texturing time. A reflectance minimum was observed when the texturing time was increased to $15 \mathrm{wt} \%$. The spectrum range of $400-800 \mathrm{~nm}$ registers the lowest reflectance is $11.27 \%$. With the reaction time increased to $15 \mathrm{~min}$, a homogeneous density of pyramidal structures on the silicon surface can be seen from the micrograph shown in Fig. 4(b). As shown in Fig. $4(c)(d)$, the SEM images of the pyramid grows excessively and the quantity of pyramids in unit area decreases, the pyramid structure is over etched and tends to lead to uneven texture surface. In this stage, the continuously increased reaction time would not signifycantly change the effect of the texture etching. Therefore, the optimal reaction time should be controlled at $15 \mathrm{~min}$.

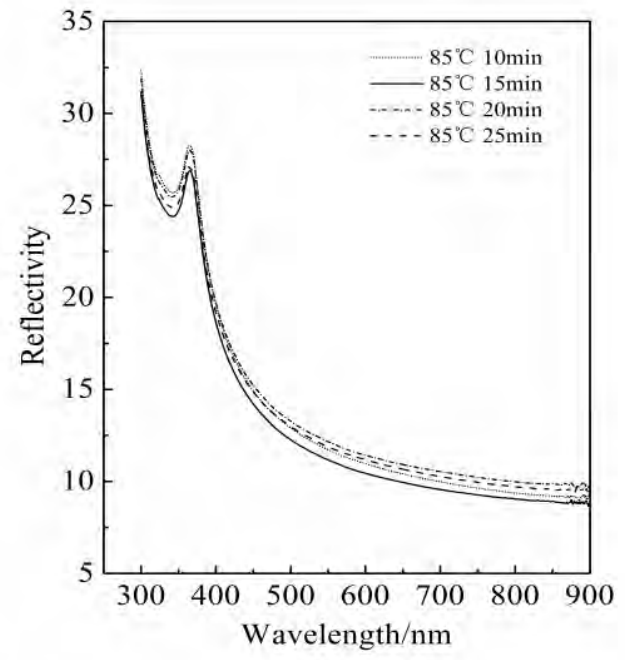

Figure 3. Reflectance curves of monocrystalline silicon wafers textured for different etching time
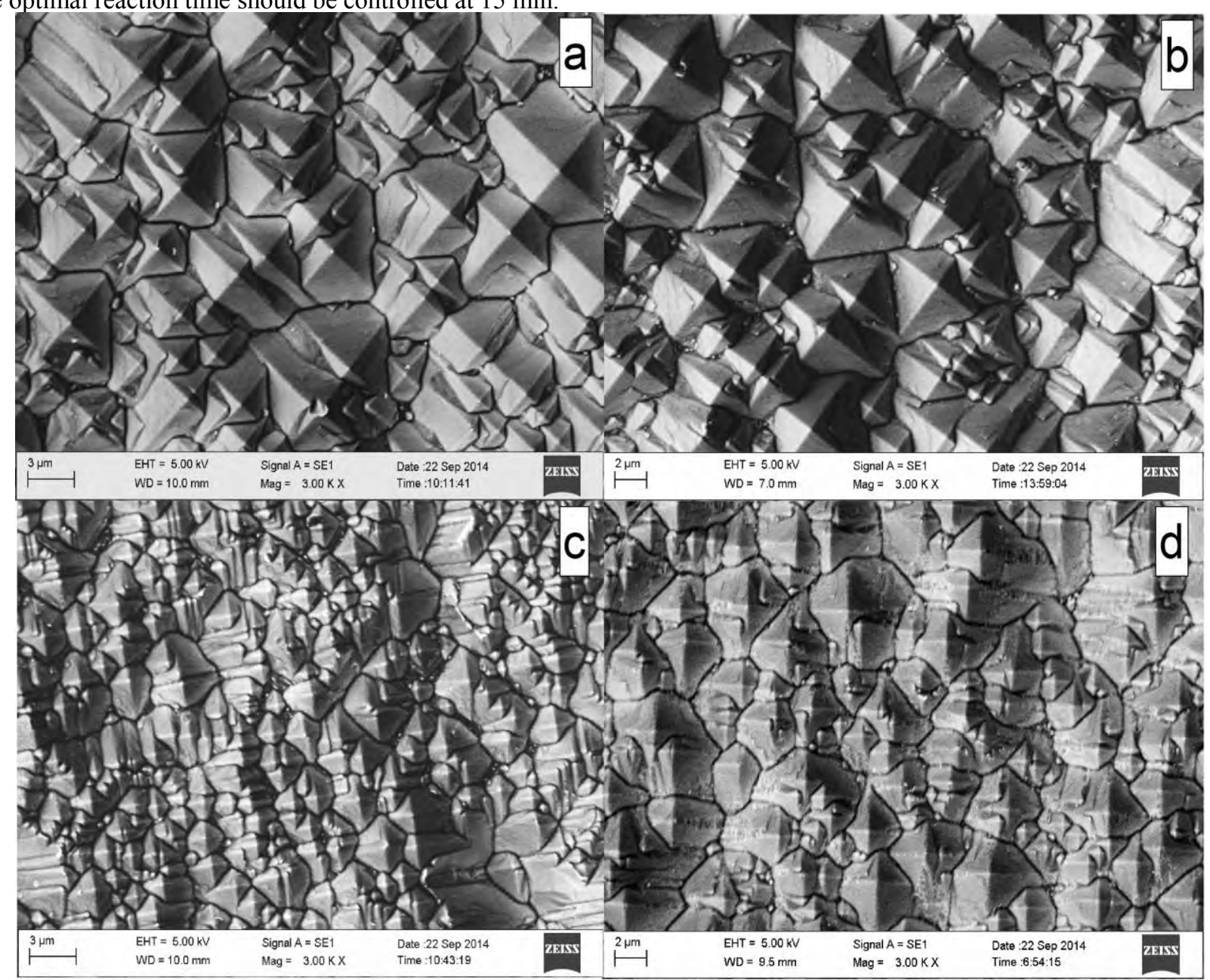

Figure 4. SEM images of monocrystalline silicon wafers textured for different etching time: (a) $10 \mathrm{~min},(\mathrm{~b}) 15 \mathrm{~min}$,(c)20 min,(d)25min

Finally, we investigated the dependence of the surface reflectance of the solution temperature. The concentration of $\mathrm{K}_{2} \mathrm{HPO}_{4}$ and $\mathrm{K}_{3} \mathrm{PO}_{4}$ was fixed at $1 \mathrm{wt} \%$ and $15 \mathrm{wt} \%$, respectively, and the etching time was also fixed at $15 \mathrm{~min}$.
The experiment was carried out from $75^{\circ} \mathrm{C}$ to $90^{\circ} \mathrm{C}$. As shown in Fig. 5, the surface reflectance decreased with increasing temperature. Under normal temperatures, alkaline solution could hardly complete the etching 
reaction on silicon wafers, and proper increase of the reaction temperature could promote the etching reaction better. While the temperature is too high, the surface structure would be over-etched by the alkaline solution and would have decreased ability to absorb the reflected lights and would not obtain ideal reflectance. By experimentally obtained to the optimum temperature is $85^{\circ} \mathrm{C}$, and the weighted average reflectance is $11.27 \%$. Fig. 6 is the SEM micrographs of monocrystalline silicon wafers textured at different temperatures. In Fig. $6(\mathrm{c})$, at $85^{\circ} \mathrm{C}$, the pyramid structure and sizes on the silicon surface are much more even compared to those in Fig. 6(d) which textured at $90^{\circ} \mathrm{C}$. Thus, the optimal reaction temperature should be $85^{\circ} \mathrm{C}$.

\section{CONCLUSION}

The texturization of monocrystalline silicon using mixed $\left(\mathrm{K}_{3} \mathrm{PO}_{4} / \mathrm{K}_{2} \mathrm{HPO}_{4}\right)$ solutions has been investigated. It is found that it is possible to optimize the reflectance values of the samples by varying the $\mathrm{K}_{3} \mathrm{PO}_{4} / \mathrm{K}_{2} \mathrm{HPO}_{4}$ concentrations of the solution, the etching time and temperature, thus obtaining low reflectance values comparable to the ones obtained in IPA based solutions. Our opti-

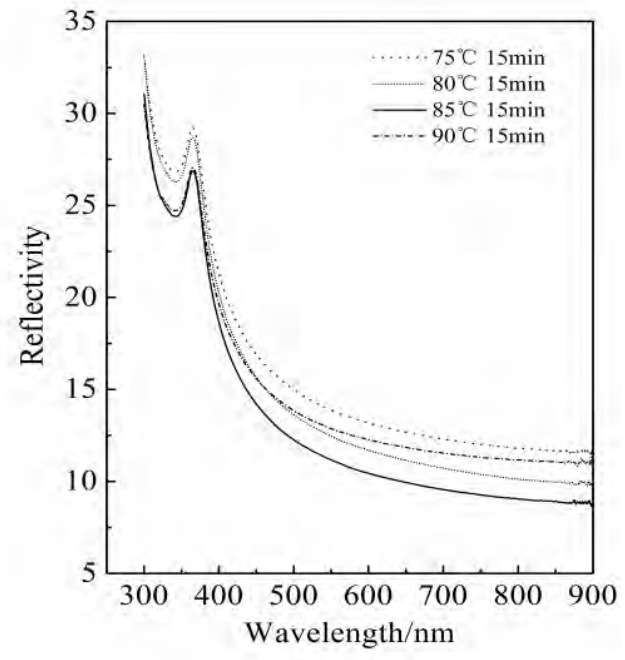

Figure 5. Reflectance curves of monocrystalline silicon wafers textured at different temperatures

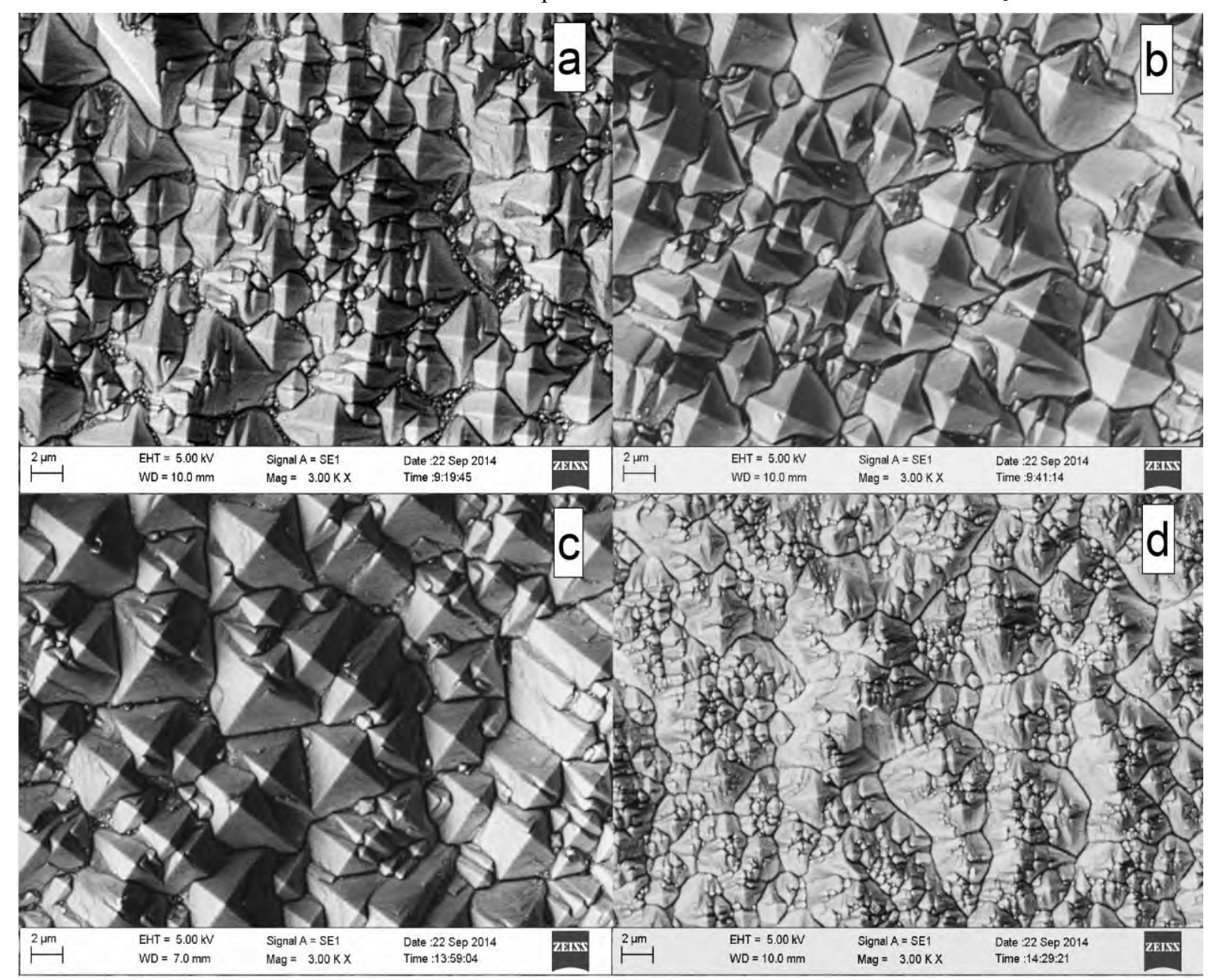

Figure 6. SEM images of monocrystalline silicon wafers textured at different temperatures: (a) $75^{\circ} \mathrm{C}$, (b) $80^{\circ} \mathrm{C}$, (c) $85^{\circ} \mathrm{C}$, (d) $90^{\circ} \mathrm{C}$

mized process lasted for $15 \mathrm{~min}$ at $85^{\circ} \mathrm{C}$ using a solution containing $15 \mathrm{wt} \% \quad \mathrm{~K}_{3} \mathrm{PO}_{4}$ and $1 \mathrm{wt} \% \quad \mathrm{~K}_{2} \mathrm{HPO}_{4}$. After texturing, for monocrystalline silicon wafers, we obtained reliable and uniform pyramidal texturing surfaces with an average weighted reflectance of $11.27 \%$. This novel approach provides an alternative way for the industrial production of high-efficiency solar cells. 


\section{ACKNOWLEDGEMENTS}

This work was supported by the National Natural Scien ce Foundation of China (NSFC) (Grant No. 21171072 and Grant No. 21361028).

\section{REFERENCES}

[1] A. Polman and H. A. Atwater, "Photonic design principles for ultrahigh-efficiency photovoltaics," Nature materials, vol. 11, no. 3 , pp. 174-177, 2012.

[2] X. Huang, S. Han, W. Huang and X. Liu, "Enhancing solar cell efficiency: the search for luminescent materials as spectral converters," Chemical Society Reviews, vol. 42, no. 1, pp. 173-201, 2013.

[3] L. Forbes, "Texturing, reflectivity, diffuse scattering and light trapping in silicon solar cells," Solar Energy, vol. 86, no. 1, pp. 319-325, 2012

[4] H. Park, S. Kwon, J. S. Lee, H. J. Lim, S. Yoon and D. Kim, "Improvement on surface texturing of single crystalline silicon for solar cells by saw-damage etching using an acidic solution," Solar Energy Materials and Solar Cells, vol. 93, no. 10, pp. 1773-1778, 2009.

[5] H. Park, J. S. Lee, S. Kwon, S. Yoon and D. Kim, "Effect of surface morphology on screen printed solar cells," Current Applied Physics, vol. 10, no. 1, pp. 113-118, 2010.

[6] F. Restrepo and C. Backus, "On black solar cells or the tetrahedral texturing of a silicon surface," Electron Devices, IEEE Transactions on, vol. 23, no. 10, pp. 1195-1197, 1976.

[7] S. Chitre, "A high volume cost efficient production macrostructuring process," in 13th Photovoltaic Specialists Conference, Ed., pp. 152-154, 1978.
[8] D. L. King and M. E. Buck, "Experimental optimization of an anisotropic etching process for random texturization of silicon solar cells," in Photovoltaic Specialists Conference, 1991. Conference Record of the Twenty Second IEEE, Ed., pp. 303-308, IEEE, 1991.

[9] Q. B. Vu, D. A. Stricker and P. M. Zavracky, "Surface characteristics of (100) silicon anisotropically etched in aqueous $\mathrm{KOH}, "$ Journal of the Electrochemical Society, vol. 143, no. 4, pp. 1372-1375, 1996.

[10] R. Barrio, N. González, J. Cárabe and J. J. Gandía, "Optimisation of $\mathrm{NaOH}$ texturisation process of silicon wafers for heterojunction solar-cells applications," Solar Energy, vol. 86, no. 3, pp. 845-854, 2012.

[11] R. Chaoui, M. Lachab, F. Chiheub and N. Seddiki, "Texturization of monocrystalline silicon with potassium carbonate solutions," in Proceedings of the 14th European Photovoltaic Solar Energy Conference. Barcelona, Spain, Ed., 1997.

[12] Y. Nishimoto and K. Namba, "Investigation of texturization for crystalline silicon solar cells with sodium carbonate solutions," Solar Energy Materials and Solar Cells, vol. 61, no. 4, pp. 393-402, 2000 .

[13] U. Gangopadhyay, K. Kim, S. Dhungel, U. Manna, P. Basu, M. Banerjee, H. Saha and J. Yi, "A novel low cost texturization method for large area commercial mono-crystalline silicon solar cells," Solar energy materials and solar cells, vol. 90, no. 20, pp. 3557-3567, 2006.

[14] Z. Xi, D. Yang and D. Que, "Texturization of monocrystalline silicon with tribasic sodium phosphate," Solar energy materials and solar cells, vol. 77, no. 3, pp. 255-263, 2003 